\title{
Infection with Rhinovirus Facilitates Allergen Penetration Across a Respiratory Epithelial Cell Layer
}

\author{
Katharina Gangl ${ }^{\mathrm{a}} \quad$ Eva E. Waltl ${ }^{\mathrm{a}}$ Helga Vetr ${ }^{\mathrm{b}}$ Clarissa R. Cabauatan ${ }^{\mathrm{c}}$ \\ Katarzyna Niespodziana ${ }^{c}$ Rudolf Valenta ${ }^{c}$ Verena Niederberger ${ }^{a}$ \\ ${ }^{a}$ Department of Otorhinolaryngology, Medical University of Vienna, ${ }^{\mathrm{b}}$ Technoclone $\mathrm{GmbH}$, and ${ }^{\mathrm{C}}$ Division of \\ Immunopathology, Department of Pathophysiology and Allergy Research, Center for Pathophysiology, \\ Infectiology and Immunology, Medical University of Vienna, Vienna, Austria
}

\section{Key Words}

Allergen penetration $\cdot$ Permeability $\cdot$ Recombinant

allergens $\cdot$ Respiratory epithelium $\cdot$ Rhinovirus barrier and allows allergens to penetrate more efficiently into the subepithelial tissues where they may cause increased allergic inflammation.

(c) 2015 S. Karger AG, Basel

\begin{abstract}
Background: Rhinovirus infections are a major risk factor for asthma exacerbations. We sought to investigate in an in vitro system whether infection with human rhinovirus reduces the integrity and barrier function of a respiratory epithelial cell layer and thus may influence allergen penetration. Methods: We cultured the human bronchial epithelial cell line 16HBE140- in a transwell culture system as a surrogate of respiratory epithelium. The cell monolayer was infected with human rhinovirus 14 at 2 different doses. The extent and effects of transepithelial allergen penetration were assessed using transepithelial resistance measurements and a panel of ${ }^{125}$-labeled purified recombinant respiratory allergens (rBet v 1, rBet v 2, and rPhl p 5). Results: Infection of respiratory cell monolayers with human rhinovirus decreased transepithelial resistance and induced a pronounced increase in allergen penetration. Conclusions: Our results indicate that infection with rhinovirus damages the respiratory epithelial
\end{abstract}

\section{Introduction}

In recent years, a clear and significant association between upper respiratory tract infections with rhinovirus and an increased frequency of asthma exacerbations in children has been shown $[1,2]$. In adults, asthma exacerbations are also associated to a substantial degree with upper respiratory tract viral infections [3]. Furthermore, asthma patients with allergic sensitization to aeroallergens have an increased risk of hospital admission for exacerbation of their disease in the presence of rhinovirus in patients' airways [4]. However, possible synergistic interactions of allergic sensitization and infection with rhinovirus have not been studied in detail. Allergen exposure via the respiratory mucosa induces strong rises of allergen-specific IgE levels, which in turn lead to increased allergen sensitivity in the target organs of allergy

\section{KARGER 125}

(c) 2015 S. Karger AG, Base

$1018-2438 / 15 / 1664-0291 \$ 39.50 / 0$

E-Mail karger@karger.com

www.karger.com/iaa
Correspondence to: Dr. Verena Niederberger

Department of Otorhinolaryngology

Vienna General Hospital, Medical University of Vienna

Waehringer Guertel 18-20, AT-1090 Vienna (Austria)

E-Mail verena.niederberger@meduniwien.ac.at 
[5]. A growing body of evidence supports the view that epithelial defects at mucosal surfaces facilitate allergen contact with underlying immune competent cells, thus contributing to the initiation or exacerbation of allergic disease and asthma [6]. Infection with rhinovirus has been shown to affect airway barrier function [7], and allergic sensitization in children has been positively linked to rhinovirus- but not other virus-associated wheezing [8]. Furthermore, high titers of IgE antibodies to house dust mite allergens have been found to be common and increase the risk of acute wheezing provoked in asthmatic children by rhinovirus [9].

In this study we aimed to investigate whether rhinovirus infection impairs airway epithelial barrier function for defined recombinant allergen molecules with a view to allergic sensitization or exacerbation of allergic disease.

\section{Methods}

\section{Culture of Human Bronchial Epithelial Cell Layers}

We cultured the epithelial cell line $16 \mathrm{HBE} 140-$, which is derived from human bronchial epithelial cells $[10,11]$. This cell line retains properties of differentiated airway epithelial cells as it grows in a polarized monolayer forming tight junctions, apical cilia, and microvilli and exhibits regulated ion transport. It can therefore be used as a surrogate of human respiratory epithelium. Cells were cultured in minimal essential medium containing $10 \%$ fetal calf serum, $100 \mathrm{U} / \mathrm{ml}$ penicillin, $100 \mu \mathrm{g} / \mathrm{ml}$ streptavidin, and $2 \mathrm{mM}$ glutamine. Cells were passaged at $80 \%$ confluence. For transwell cell culture experiments, $2 \times 10^{5}$ cells were seeded in the upper chambers of 12-mm-diameter transwell inserts (polyester membrane, $0.4-\mu \mathrm{m}$ pore size; Costar, Cambridge, Mass., USA); the upper and lower chambers contained 500 and 1,500 $\mu \mathrm{l}$ medium, respectively.

\section{Rhinovirus Infection}

Human rhinovirus 14 (HRV14) was obtained from ATCC (Manassas, Va., USA) and used for infection after growth in suspension cultures of HeLa cells (Ohio strain; Flow Laboratories, McLean, Va., USA) for $40 \mathrm{~h}$, preparation by polyethylene glycol precipitation, and resuspension in PBS as described previously [12]. Apical infection of epithelial monolayers with HRV14 was performed on confluent $16 \mathrm{HBE} 14 \mathrm{o}-$ cells. Cell confluence was ascertained by phase contrast microscopy $(\times 4$ objective, Olympus IX73; Tokio, Japan) and corresponded to transepithelial resistance (TER) measurements exceeding $200 \Omega \cdot \mathrm{cm}^{2}$. Multiples $(100$ and 1,000$)$ of the previously determined $50 \%$ tissue culture infective dose (TCID50)/cell corresponding to multiplicity of infection values of 70 and 700, respectively, were used for infection. Confluent cell monolayers were apically infected in minimal essential medium containing $2 \%$ fetal calf serum, $100 \mathrm{U} / \mathrm{ml}$ penicillin, 100 $\mu \mathrm{g} / \mathrm{ml}$ streptavidin, and $2 \mathrm{~mm}$ glutamine (all from Gibco Life Technologies) at $34^{\circ} \mathrm{C}$. One hour after infection the unincorporated virus was removed by washing with minimal essential medium containing $10 \%$ fetal calf serum, $100 \mathrm{U} / \mathrm{ml}$ penicillin, $100 \mu \mathrm{g} /$ $\mathrm{ml}$ streptavidin, and $2 \mathrm{~mm}$ glutamine and incubation was continued at $37^{\circ} \mathrm{C}$. In control wells, mock infection was performed by adding PBS.

\section{Assessment of Cytopathogenicity}

Cells were inspected visually by phase contrast microscopy ( $4 \times$ objective, Olympus IX73; Tokio, Japan) and images were recorded (Olympus DP73; Tokio, Japan). Cytopathogenicity was assessed with a crystal violet assay. 16HBE14o- cells were seeded in 96-well microtiter plates at $2 \times 10^{5}$ cells/well and incubated for $11 \mathrm{~h}, 30 \mathrm{~h}$, and 5 days with $100 \times$ or $1,000 \times$ TCID50/cell of HRV14 according to the above-described infection protocol, or mock infection was performed. Cells were stained with $150 \mu \mathrm{l} /$ well $0.1 \%$ crystal violet in acetic acid/ $\mathrm{dH}_{2} \mathrm{O}$ for $10 \mathrm{~min}$ at $21^{\circ} \mathrm{C}$. The crystal violet solution was then removed and wells were gently washed with $\mathrm{dH}_{2} \mathrm{O}$. Microtiter plates were inspected visually and photographed. Viable cells are stained blue by crystal violet.

Measurement of Transepithelial Resistance under the Influence of Different Concentrations of Rhinovirus

Epithelial barrier function was assessed by measuring TER using an ohm voltmeter (Millipore, Bedford, Mass., USA), as described previously [13]. Baseline resistance values across polyester membranes without cellular monolayers were $100 \Omega \cdot \mathrm{cm}^{2}$ on average and were subtracted from TER measurements. Experiments investigating the effect of rhinovirus infection on epithelial barrier function were initiated when the TER reached at least $300 \Omega \cdot \mathrm{cm}^{2}$. HRV14 (100× and 1,000× TCID50/cell) was added to the upper chamber of the transwell system and TER was measured 11 and $30 \mathrm{~h}$ after the infection. Experiments were conducted 2 times in duplicate and 1 time in triplicate wells. Data are presented as the means and SD of these experiments.

Incubation of an Epithelial Cell Layer with Allergen before and during Infection with Rhinovirus

Recombinant (r) Bet v 1 (17 kDa), the major birch pollen allergen, and $\mathrm{rPhl}$ p $5(28 \mathrm{kDa})$, a major Timothy grass pollen allergen, were obtained from Biomay (Vienna, Austria). A dose of $0.2 \mu \mathrm{g} / \mathrm{ml}$ allergen was added to apical chambers of the transwell system when cells reached TER values of $200 \Omega \cdot \mathrm{cm}^{2}$ and cell layers were incubated for $2 \mathrm{~h}$ at $37^{\circ} \mathrm{C}$. HRV14 $(100 \times$ and $1,000 \times$ TCID50/cell) was used to infect $16 \mathrm{HBE} 14 \mathrm{o}-$ cell monolayers and TER was measured 11 and $30 \mathrm{~h}$ after the infection. In a variation of the experiment, amounts of allergen similar to those described above were added $1 \mathrm{~h}$ after infection of the cells with rhinovirus.

\section{Quantification of Transepithelial Allergen Migration}

rBet v $1(17 \mathrm{kDa})$, rBet v $2(14 \mathrm{kDa})$, and rPhl p $5(28 \mathrm{kDa})$ (all from Biomay) were ${ }^{125} \mathrm{I}$-labeled using the chloramin $\mathrm{T}$ method [14]. ${ }^{125}$ I-labeled allergens $\left(10^{6}\right.$ counts/min $(\mathrm{cpm}) /$ well $)$ were added to the upper chamber of the transwell system $1 \mathrm{~h}$ after infection of cells with HRV14 (100× and 1,000× TCID50/cell), or mock infection was performed. Three hours thereafter, equivalent aliquots (50 and $150 \mu \mathrm{l}$, respectively) from the upper and the lower chamber were analyzed in a gamma counter (Wallac, Turku, Finland). Cells were removed from the membrane and lysed for determination of intracellular radioactivity. Counts per minute were determined for both chambers and the cell layer. All experiments and measurements were repeated at different time points. 
SDS-PAGE and Autoradiography

Equivalent aliquots from the upper and lower chambers of the transwell system containing ${ }^{125} \mathrm{I}$-labeled allergens were separated by electrophoresis on a $12.5 \%$ sodium dodecyl sulfate-polyacrylamide gel, which also contained a molecular weight marker. Gels were sealed and directly autoradiographed using Kodak X-Omat S films and intensifying screens.

\section{Statistics}

TER measurements after $30 \mathrm{~h}$ of HRV14 infection were analyzed for comparison of the two HRV14 concentrations with mock infection by one-way analysis of variance (ANOVA) and subsequent $t$ tests with a Bonferroni correction for post hoc multiple testing (Excel 2010; Microsoft). $\mathrm{p}<0.05$ was considered statistically significant for ANOVA testing. For the subsequent 2 post hoc t tests (mock infection vs. 100 $\times$ TCID50 and mock infection vs. $1,000 \times$ TCID50), $\mathrm{p}<0.025$ was considered statistically significant for corrected testing.

Radioactive penetration experiments were considered as results from an explorative study. Mean values were therefore analyzed using t tests to compare the mock infection control with each HRV14 concentration. $\mathrm{p}<0.05$ was considered statistically significant.

\section{Results}

\section{Exposure of an Epithelial Cell Monolayer to}

Rhinovirus Induces a Decrease in TER

We investigated whether apical infection of confluent 16HBE140- cell monolayers with 2 different concentrations of HRV $14(100 \times$ and 1,000 $\times$ TCID50/cell) could affect TER. The development of TER before and after infection is shown in figure 1. The TER in mock infected wells increased from $374 \pm 88$ to $499 \pm 117 \Omega \cdot \mathrm{cm}^{2}$ after $11 \mathrm{~h}$ and to $648 \pm 138 \Omega \cdot \mathrm{cm}^{2}$ after $30 \mathrm{~h}$. Infection with $1,000 \times$ TCID50/cell led to a marked drop in TER from $403 \pm 63$ to $269 \pm 225 \Omega \cdot \mathrm{cm}^{2}$ after $11 \mathrm{~h}$, which further intensified at $30 \mathrm{~h}$ after infection to $60 \pm 48 \Omega \cdot \mathrm{cm}^{2}(30 \mathrm{~h}: \mathrm{p}=0.008)$. Changes in wells which were infected with 100× TCID50/ cell were less pronounced, decreasing from $383 \pm 80$ to $325 \pm 162 \Omega \cdot \mathrm{cm}^{2}$ at $30 \mathrm{~h}$ after the infection $(30 \mathrm{~h}: \mathrm{p}=$ $0.003)$.

\section{No Cytopathogenic Events Were Observed 11 and $30 \mathrm{~h}$ after Infection}

When cells were monitored visually during HRV14 infection with $100 \times$ and 1,000× TCID50/cell, no cytopathogenetic events (CPE) were seen 11 and $30 \mathrm{~h}$ after infection. In crystal violet assays no CPE were seen at any time point in uninfected cells or cells infected with $100 \times$ TCID50/ cell. At 1,000× TCID50/cell of HRV14 no CPE were seen 11 and $30 \mathrm{~h}$ after infection; however, 5 days after infection complete CPE were seen in infected wells (table 1).

Rhinovirus Facilitates Allergen

Penetration

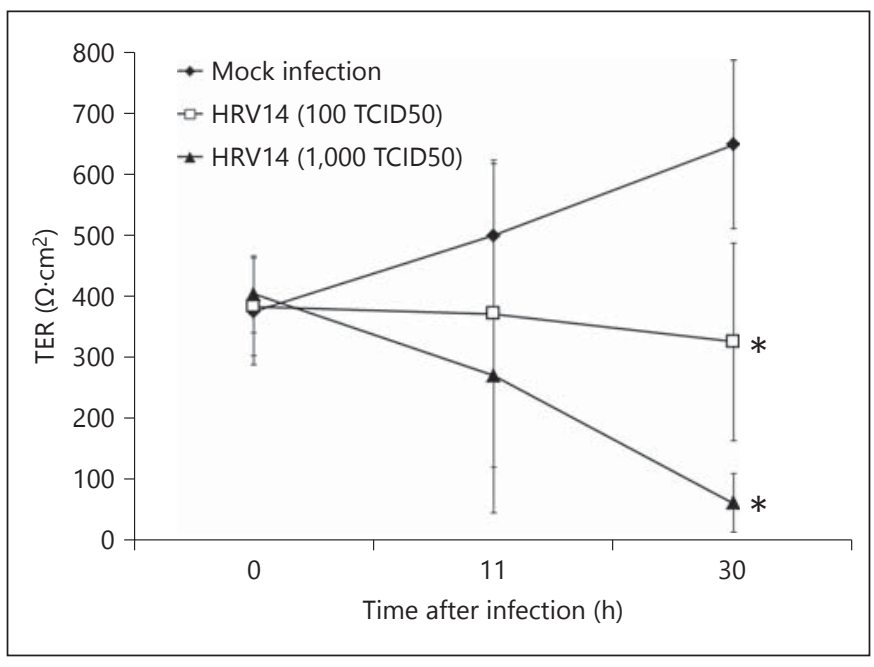

Fig. 1. Infection of an epithelial cell monolayer with rhinovirus leads to a decrease in TER. 16HBE14o- monolayers that had been cultured on a semipermeable membrane in a transwell system were apically exposed to 2 different concentrations of HRV 14 (100 $\times$ and $1,000 \times$ TCID50/cell), or mock infection was performed. Changes in TER are shown for different time points. Data points represent the mean values of 3 separate experiments. SD are displayed. Statistically significant differences between mock infection and each of the 2 concentrations of HRV 14 were observed $30 \mathrm{~h}$ after infection $(* \mathrm{p}<0.025)$

Table 1. Lack of CPE during the first $30 \mathrm{~h}$ of HRV14 infection

\begin{tabular}{llll}
\hline & $11 \mathrm{~h}$ & $30 \mathrm{~h}$ & 5 days \\
\hline Mock infection & + & + & + \\
$100 \times$ TCID50 & + & + & + \\
$1,000 \times$ TCID50 & + & + & -
\end{tabular}

$16 \mathrm{HBE} 14 \mathrm{o}-$ cells were seeded at a density of $2 \times 10^{5}$ cells/well in 96-well microtiter plates and infected with 2 concentrations of HRV14 (100× and 1,000× TCID50/cell) or by mock infection and incubated for $11 \mathrm{~h}, 30 \mathrm{~h}$, and 5 days. The respective CPE observed are indicated. $+=$ Viable cells; $-=$ complete $\mathrm{CPE}$.

Incubation with Allergen before and during Infection of an Epithelial Cell Monolayer with Rhinovirus Does Not Further Decrease TER

16HBE14o- monolayers cultured on a semipermeable membrane in a transwell system were incubated apically for $2 \mathrm{~h}$ with $0.2 \mu \mathrm{g} / \mathrm{ml} \mathrm{rBet} \mathrm{v1} \mathrm{or} \mathrm{rPhl} \mathrm{p} \mathrm{5,} \mathrm{or} \mathrm{no} \mathrm{incuba-}$ tion with allergen was performed. The allergen amount $(0.2 \mu \mathrm{g} / \mathrm{ml})$ was chosen because it corresponds to the amount of allergen a patient is exposed to during a day of high pollen season $[15,16]$. Cell monolayers were then 
infected apically with $100 \times$ or $1,000 \times$ TCID $50 /$ cell of HRV14, or mock infection was performed.

Thirty hours after infection, only minimal changes in TER were observed in cells which had been preincubated with allergens compared to cells preincubated with medium (preincubation with rBet v 1: $+0.6 \%$ (HRV14; 100× TCID50) and $+4 \%$ (HRV 14; $1,000 \times$ TCID50); preincubation with rPhl p 5: $-4 \%$ (HRV14; 100× TCID50) and $-5 \%$ (HRV14; 1,000× TCID50)) Furthermore, allergen exposure without rhinovirus did not alter TER compared to the control medium ( -2 to $+4 \%$ difference in TER between allergen exposure and the control medium).

A variation of this experiment, where cell monolayers were infected first with $100 \times$ or $1,000 \times$ TCID50/cell of HRV 14, with addition of rPhl $\mathrm{p} 5$ or rBet $\mathrm{v} 1$ one hour after infection yielded similar results of TER after $30 \mathrm{~h}$ of incubation, i.e. rPhl p 5: $-9 \%$ (HRV 14; 100× TCID50) and $-15 \%$ (HRV14; 1,000× TCID50), and rBet v 1: +7\% (HRV14; $100 \times$ TCID50) and $+5 \%$ (HRV 14; 1,000× TCID50).

\section{Rhinovirus Exposure Facilitates Allergen Penetration across Epithelial Cell Layers}

We measured the permeability of the 16HBE14o- cell layer for 3 different unrelated ${ }^{125}$ I-labeled allergens from different allergen sources ( $r B e t v 1$ and $\mathrm{rBet} v \mathrm{v}$ : birch pollen; $\mathrm{rPhl} p$ 5: grass pollen) after infection of cell monolayers with $100 \times$ and $1,000 \times$ TCID50/cell of HRV14. In figure 2 results are displayed as cpm lower chamber/cpm upper chamber in percent. The permeability for Phl p 5 started to increase after infection with 100× TCID50/cell of HRV14 (triangles in fig. 2) and was strongly augmented for all allergens at 1,000 $\times$ TCID50/cell (circles in fig. 2) compared to the wells where mock infection had been performed (asterisks in fig. 2) $(1,000 \times$ TCID50: $\mathrm{p}<0.05)$. Less than $5 \%$ of radioactively labeled allergen was detected in the lower chambers, when the epithelial layer was intact, as observed previously [13]. Similar effects on allergen permeability were seen when the infection time and the penetration time were increased (data not shown). No radio-labeled allergens were detected within the cell layer, indicating paracellular penetration, as already observed previously [13].

\section{Allergens Remain Intact during Transepithelial \\ Penetration}

To visualize the extent of allergen penetration and its impact on allergen integrity, aliquots of supernatants of the upper and lower chambers were removed and analyzed by SDS-PAGE. An autoradiography of a representative penetration experiment with rBet $\mathrm{v} 1$ is displayed

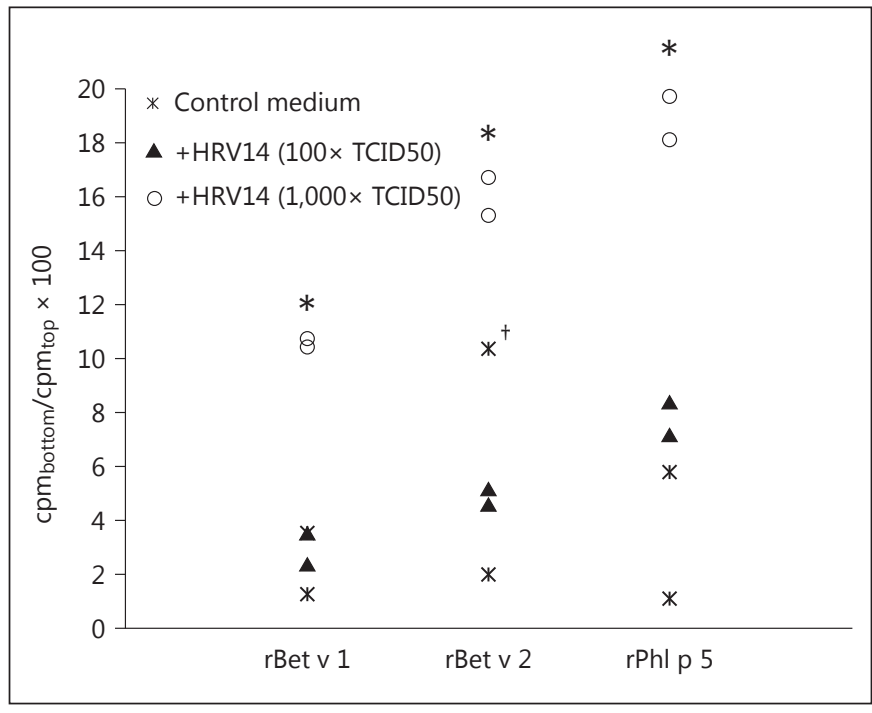

Fig. 2. Rhinovirus exposure increases intact allergen penetration across epithelial cell layers. Different doses of HRV14 (100× and $1,000 \times$ TCID50/cell) were used to infect confluent monolayers of $16 \mathrm{HBE} 14 \mathrm{o}-$ cells that had been cultured on a semipermeable membrane in a transwell system. Then ${ }^{125}$ I-labeled rBet v 1 , rBet v 2 , or $\mathrm{rPhl} p 5$ was added to the upper chamber. The percentage of allergen that penetrated to the lower chamber after $3 \mathrm{~h}$ is displayed on the $y$-axis. ${ }^{\dagger}=$ One outlier among all of the mock infections. $* \mathrm{p}<0.05$ compared to mock infection.

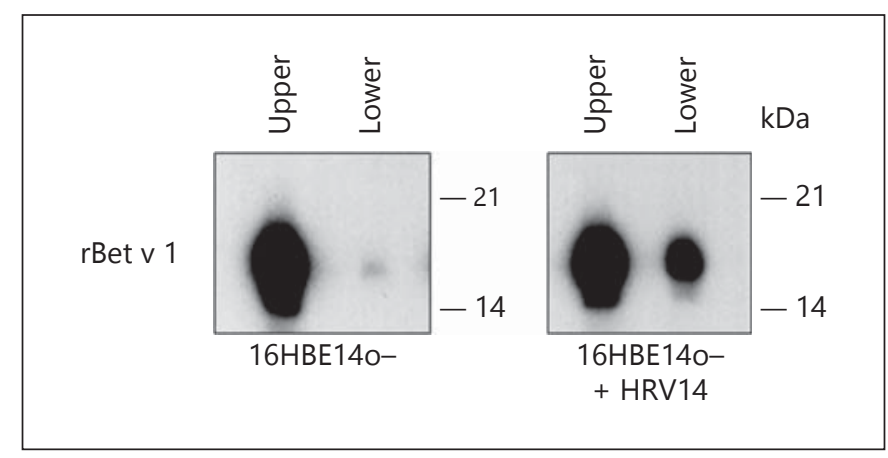

Fig. 3. Allergen remains intact during transepithelial penetration. Aliquots from upper and lower chambers that had been infected with 1,000 $\times$ TCID50/cell of HRV14 (right) or with mock infection (left) and had then been incubated for $6 \mathrm{~h}$ after addition of ${ }^{125} \mathrm{I}$-labeled rBet v 1 were separated by SDS-PAGE and by autoradiography.

in figure 3. After infection with 1,000× TCID50 / cell of HRV14 and a penetration time of $6 \mathrm{~h}$, a considerable amount of $r B e t v 1$ penetrated to the lower chamber of the transwell system, whereas almost no rBet $\mathrm{v} 1$ was found in the lower chamber of a transwell system where a mock infection had been performed. rBet $\mathrm{v} 1$ appeared at 17 $\mathrm{kDa}$. Similar results were obtained with $\mathrm{rBet} \mathrm{v} 2$ and $\mathrm{rPhl}$ 
p 5. Control experiments performed with proteins with a larger molecular weight compared to the allergens (e.g. serum albumin) showed that protein penetration was not dependent on the molecular weight (data not shown).

\section{Discussion}

In this study we used purified clinically relevant respiratory allergens from birch pollen and grass pollen to investigate the impact of rhinovirus infection on the permeability of a respiratory epithelial cell layer for allergens. We found that rhinovirus infection impaired the barrier function of respiratory epithelium and increased permeability for each of the respiratory allergens we tested. Coexposure of allergen and rhinovirus did not increase the observed effects in our experiments.

Our observation may explain why rhinovirus-induced asthma exacerbations in allergic individuals are more severe when the allergen is present at the time of viral infection [4]. It is well known that respiratory allergen contact strongly boosts the secondary IgE response to allergens and allergen-specific sensitivity [5]. Rhinovirus-induced increased allergen penetration may lead to increased stimulation of mast cells, cells producing allergen-specific IgE, and $\mathrm{T}$ cells. In fact, it was recently reported that high levels of house dust mite allergen-specific IgE are common and increase the risk of acute wheezing induced by rhinovirus in asthmatic children [9].rBet $\mathrm{v} 1$ and $\mathrm{rPhl} \mathrm{p} 5$, which were used in our experiments, are equivalent to their natural counterparts in terms of biochemical and immunological characteristics $[17,18]$. These allergens are rapidly released when pollen grains come into contact with isotonic media such as nasal secretions $[19,20]$. One can therefore assume that they are indeed present at the epithelial barrier and that the recombinant proteins correspond to the natural counterparts. Moreover, by using pure recombinant allergens without intrinsic protease activity, we made sure that increased allergen penetration could be imputed neither to extraneous protease activity from other components, which might be present in allergen extracts, nor to the synergistic invasive effect of bacteria, e.g. Hemophilus influenzae, which has been described to be greatly increased by rhinovirus infection [7].

It emerges that infection with rhinovirus may be an important risk factor in allergic asthma patients and needs to be prevented. Other viruses such as respiratory syncytial virus and influenza virus were not studied in our model, although they are also known to cause asthma exacerbations in children and adults [21]. It would thus be interesting to conduct further studies in our model with these viruses.

In summary, we have shown that infection with rhinovirus impairs the barrier function of a respiratory epithelial cell layer and facilitates transepithelial penetration of allergens, thereby potentially increasing submucosal allergen concentrations and aggravating allergic disease.

\section{Acknowledgements}

Some experiments for this study were performed in collaboration with Prof. Ernst Kuechler from Max F. Perutz Laboratories, Medical University of Vienna, Vienna, Austria, who sadly passed away before this study was finished.

Statistical calculations were performed following consultation with the Department of Medical Statistics of the Medical University of Vienna. Grant support was provided by projects F4605 and F4613 of the Austrian Science Fund (FWF) and in part by the EUfunded FP7 research program Predicta.

\section{References}

1 Holgate ST: The sentinel role of the airway epithelium in asthma pathogenesis. Immunol Rev 2011;242:205-219.

2 Khetsuriani N, Kazerouni NN, Erdman DD, Lu X, Redd SC, Anderson LJ, Teague WG: Prevalence of viral respiratory tract infections in children with asthma. J Allergy Clin Immunol 2007;119:314-321.

3 Friedlander SL, Busse WW: The role of rhinovirus in asthma exacerbations. J Allergy Clin Immunol 2005; 116:267-273.

4 Green RM, Custovic A, Sanderson G, Hunter J, Johnston SL, Woodcock A: Synergism between allergens and viruses and risk of hospital admission with asthma: case control study. BMJ 2002;324:1-5.
5 Niederberger V, Ring J, Rakoski J, Jager S, Spitzauer S, Valent P, Horak F, Kundi M, Valenta R: Antigens drive IgE responses in human allergy via the nasal mucosa. Int Arch Allergy Immunol 2007;142:133-144.

6 Golebski K, Röschmann KI, Toppila-Salmi S, Hammad H, Lambrecht BN, Renkonen R, Fokkens WJ, van Drunen CM: The multi-faceted role of allergen exposure to the local airway mucosa. Allergy 2013;68: $152-160$.

7 Sajjan U, Wang Q, Zhao Y, Gruenert DC, Hershenson MB: Rhinovirus disrupts the barrier function of polarized airway epithelial cells. Am J Respir Crit Care Med 2008;178: 1271-1281.
8 Jartti T, Kuusipalo H, Vuorinen T, Söderlund-Venermo $M$, Allander T, Waris $M$, Hartiala J, Ruuskanen O: Allergic sensitization is associated with rhinovirus-, but not other virus-, induced wheezing in children. Pediatr Allergy Immunol 2010;21:10081014.

9 Sotos-Quiros M, Avila L, Platts-Mills TA, Hunt JF, Erdman DD, Carper H, Murphy DD, Odio S, James HR, Patrie JT, Hunt W, O’Rourke AK, Davis MD, Steinke JW, Lu X, Kennedy J, Heymann PW: High titers of IgE antibody to house dust mite allergen and risk for wheezing among asthmatic children infected with rhinovirus. J Allergy Clin Immunol 2012;129:1499-1505. 
10 Wan H, Winton HL, Soeller C, Stewart GA, Thompson PJ, Gruenert DC, Cannell MB, Garrod DR, Robinson C: Tight junction properties of the immortalized human bronchial epithelial cell lines Calu-3 and 16HBE140-. Eu Respir J 2000;15:1058-1068.

11 Forbes B, Shah A, Martin GP, Lansley AB: The human bronchial epithelial cell line $16 \mathrm{HBE} 14 \mathrm{o}-$ as a model system of the airways for studying drug transport. Int J Pharm 2003; 257:161-167.

12 Stöckl J, Vetr H, Majdic O, Zlabinger G, Kuechler E, Knapp W: Human major group rhinoviruses downmodulate the accessory function of monocytes by inducing IL-10. J Clin Invest 1999;104:957-965.

13 Reisinger J, Triendl A, Küchler E Bohle B, Krauth MT, Rauter I, Valent P, Koenig F, Valenta $R$, Niederberger V: IFN-gamma-enhanced allergen penetration across respiratory epithelium augments allergic inflammation. J Allergy Clin Immunol 2005;115: 973-981.

14 Sambrook J, Fritsch EF, Maniatis T: Molecular Cloning: a Laboratory Manual. Cold Spring Harbor, Cold Spring Harbour Laboratory Press, 1989.

15 Schäppi GF, Taylor PE, Pain MC, Cameron PA, Dent AW, Staff IA, Suphioglu C: Concen- trations of major grass group 5 allergens in pollen grains and atmospheric particles: implications for hay fever and allergic asthma sufferers sensitized to grass pollen allergens. Clin Exp Allergy 1999;29:633-641.

16 Egger C, Lupinek C, Ristl R, Lemell P, Horak F, Zieglmayer P, Spitzauer S, Valenta R, Niederberger V: Effects of nasal corticosteroids on boosts of systemic allergen-specific IgE production induced by nasal allergen exposure. PLoS One 2015;10:e114991.

17 Ferreira FD, Hoffmann-Sommergruber K, Breiteneder H, Pettenburger K, Ebner C, Sommergruber W, Steiner R, Bohle B, Sperr WR, Valent P, Kungl AJ, Breitenbach M, Kraft D, Scheiner O: Purification and characterization of recombinant Bet $\mathrm{v}$ I, the major birch pollen allergen: immunological equivalence to natural Bet v I. J Biol Chem 1993;268: 19574-19580.

18 Vrtala S, Sperr WR, Reimitzer I, van Ree R, Laffer S, Müller WD, Valent P, Lechner K, Rumpold H, Kraft D, Scheiner O, Valenta R: cDNA cloning of a major allergen from timothy grass (Phleum pratense) pollen: characterization of the recombinant $\mathrm{Phl} \mathrm{pV}$ allergen. J Immunol 1993;151:4773-4781.

19 Vrtala S, Grote M, Duchêne M, van Ree R, Kraft D, Scheiner O, Valenta R: Properties of tree and grass pollen allergens: reinvestigation of the linkage between solubility and allergenicity. Int Arch Allergy Immunol 1993; 102:160-169.

20 Grote M, Vrtala S, Niederberger V, Wiermann R, Valenta R, Reichelt R: Release of allergen-bearing cytoplasm from hydrated pollen: a mechanism common to a variety of grass (Poaceae) species revealed by electron microscopy. J Allergy Clin Immunol 2001; 108:109-115.

21 Papadopoulos NG, Christodoulou I, Rohde G, Agache I, Almqvist C, Bruno A, Bonini S, Bont L, Bossios A, Bousquet J, Braido F, Brusselle G, Canonica GW, Carlsen KH, Chanez P, Fokkens WJ, Garcia-Garcia M, Gjomarkaj M, Haahtela T, Holgate ST, Johnston SL, Konstantinou G, Kowalski M, Lewandowska-Polak A, Lødrup-Carlsen K, Mäkelä M, Malkusova I, Mullol J, Nieto A, Eller E, Ozdemir C, Panzner P, Popov T, Psarras S, Roumpedaki E, Rukhadze M, Stipic-Markovic A, Todo Bom A, Toskala $E$, van Cauwenberge $P$, van Drunen C, Watelet JB, Xatzipsalti M, Xepapadaki P, Zuberbier $\mathrm{T}$ : Viruses and bacteria in acute asthma exacerbations - a GA ${ }^{2}$ LEN-DARE systematic review. Allergy 2011;66:458468. 